\title{
脳波を用いた環境音の快適性評価*
}

\author{
平 澤 瞬*1, 渡 邊 鉄 也*2, 田中 基八郎*3
}

\section{Evaluation of Environmental Comfort Sound by Electroencephalogram}

\author{
Shun HIRASAWA, Tetsuya WATANABE*4 and Kihachiro TANAKA
}

${ }^{* 4}$ Division of Mechanical Engineering and Science, Saitama University, 255 Shimo-Okubo, Sakura-ku, Saitama-shi, Saitama, 338-8570 Japan

\begin{abstract}
We are surrounded by various sounds like the sound of the car, train, rain and all that in our daily life. It might become feelings very relieved, and come to want to prevent our ear unpleasantly at times. Then, it is thought that it is possible to pursue comfort of the specific sound source like an artificial machine noise by evaluating emotion caused by the sound. There are two methods of evaluating emotion. One is the subjective evaluation like the semantic differential method and the other is the objective evaluation method using biological information, such as electroencephalogram and electrocardiogram. And, a latter method is more certain and quantitative. This study establishes the method for quantitatively evaluating the comfort by measuring electroencephalogram. Then, an objective evaluation to an environmental sound is evaluated by this method.
\end{abstract}

Key Words : Electroencephalogram, Comfort Evaluation, Environmental Sound

\section{1. 粕 言}

私たちは日常の中で, 車や電車の音, 鳥のさえずり, 雨音, 工事現場の音といった様々な音（環境音）に囲 まれて生活している. そして，それぞれの音に対して ある感情を持ち，とても安らぐ気持ちになる場合もあ るし，時には不快で耳を防ぎたくなる場合もある，そ こで, 音によって生まれる感情を評価することにより, どのような音が心地よいか，あるいは不快であるかな ど, 特定音源の快適性を追求することができると考え られる. 特に機械音などの人工的な音に対する快適性 を評価することは空間環境の改善, そして人々が過ご しやすい環境の構築につながると考える.

このような感情を評価するにあたり，一般的に用い られているのは SD 法などの主観的な評価方法(1)であ る.しかし，より確害に，定量的に評価をするために は主観的な手法に加えて, 客観的な手法が求められて いる. そしてそれは心拍, 脈波, 脳波といった心理状 態に呼応する生理応答をみることで可能となる.

* 原稿受付 2010 年 3 月 26 日。

*1 学生員, 埼玉大学大学院理工学研究科(恋338-8570 さいた ま市桜区下大久保 255 ).

*2 正員, 埼玉大学大学院理工学研究科.

*3 正員, フェロ一, 埼玉大学大学院理工学研究科.

E-mail: watanabe@mech.saitama-u.ac.jp
本研究では，環境音と感情の関倸性を解明するため に，人間の生体情報の一つである脳波を用いて定量的 な評価を行う．脳波は人間工学的分野に広く利用され ているが，その多くは脳波の主成分の変化に焦点を当 てたものである.これまでも快適性を $\alpha$ 波成分の増加 で評価しようとする研究が行われてきた. しかし，畄 の活動度は個人差が大きく外来ノイズに弱いという欠 点がある. そこで本研究では比較的個人差が少なく， 外来ノイズに強い脳波の周波数ゆらぎに注目する。ゆ らぎは，製品としても利用されており，特に音楽自体 にゆらぎ成分（1/f音楽など）を持たせるリラックス音 楽は広く知られている. しかし，このように製品に対 してゆらぎ成分を持たせる研究は多く行われているが， 心拍や脈波, 脳波などの生体情報のゆらぎを工学的に 利用する研究(2)は少ない.人間の生体情報は非常に複 雑であり，今なお解明されていない部分が多く，もし 周波数ゆらぎなどの情報を利用することができれば, 工学的に非常に有益なものとなると考えられる.

本研究では，脳波の周波数ゆらぎなどによる快適性 評価方法について検討を行い，私たちの身の回りにあ る環境音に対する快適性を主観的，客観的の両側面加 ら評価する．また，ストレスに関連があると言われて いる $\alpha 1$ 波 ${ }^{(3)}$ の割合の時間推移を見ることで, 環境音と それに対する「慣れ」の関連性を調査する. 


\section{2. 快啇性評価方法}

$2 \cdot 1$ 脳波 大脳皮質恒多数の神経細胞（ニュー ロン）で構成されている．す心゙ての刺激は何らかの形 で脳に伝わり，それに対して脳が判断を下寸．脳での 情報処理はニューロン同士の情報伝達によって行われ るが，その際にニューロンは発火し電気信号によって 情報を伝達寸る. このニューロン 1 つの発火による電 位は非常に小さいものだが，大脳皮質を覆う頭蓋骨上 の頭皮には多数のニューロン発火の合計が表れる。こ の電位波形が脳波, (Electroencephalogram)である. 脳波 には自発脑波と誘発脑波があり，前者は常に出現する 定常的な脑波であり，背景脳波とも呼ばれることもあ る. それに対し，後者は何らかの課題や刺激を与えた ときに出現する過渡的なものである，自発脳波は振幅 数十 $\mu \mathrm{V}$, 周波数 $0.5 \sim 100 \mathrm{~Hz}$ 程度の波形であり，様々 な周波数の波が混在している状態であるが，周波数成 分ごとに分類がされている（基本律動）。一般的に $\delta$ 波 (2〜4Hz) は睡眠時， $\theta$ 波 $(4 \sim 8 \mathrm{~Hz})$ は覚醒レベル が低く，ボーっとした状態， $\alpha$ 波（8～13Hz）は落ち 着いた状態や安静閉眼時に優位になり， $\beta$ 波 $(13 \mathrm{~Hz} \sim)$ は開眼時や精神活動時に優位になることが知られてい る. また，本研究では $\alpha$ 波を $\alpha 1$ 波（8～10Hz） と $\alpha 2$ 波 $(10 \sim 13 \mathrm{~Hz})$ に分けて扱う.

$2 \cdot 2$ 感情モデル 人閒の感情は非常に複雑で多 彩であるため，感情を完全に把握することは困難であ る. 基本的な感情の識別はさまざまな研究者によって 試みられている. エクマンは「幸福」怒り」驚き」「悲 しみ」「嫌悪」「恐れ」の6感情が基本であるとし，万 国共通といわれている感情と等しい：また，イザード は「興味・興奮」「喜び」「驚き」「苦悩・不安」「怒 り」「嫌悪」「軽茂」「恐れ」「恥」「罪悪感」の10 感情を基本感情としている．また，プラチックは「歓 喜」「憧憬」「恐怖」「驚嘆」「悲嘆」「増悪」「激 怒」「警戒」の8つの感情とそれぞれにその感情の強 度を加えた 3 次元的なモデルを提案している(4). 一方, ヘラーは気分の良し悪し (Valence) と覚醒 (Arousal) の 2 次元で感情を表現するモデルを提案した ${ }^{(5)}$ ．さら に, Valence と Arousal の 2 軸によって分割される4つ の象限で感情を「Calm（落ち着いた）」「Happy（嬉 しい)」「Anxious (不安)」「Depressed (落ち込んだ)」 の 4 種類に区別している. エクマンやイザードらが考 えたものに比べれば，単純化されているが，人の感情 を簡便に評価するために，本研究ではこの感情の 2 次 元モデル（図1）を参考にして感情評価を行う.
$2 \cdot 3$ 脳波のゆらぎ 脳波の時刻歴波形を見ると その周期は時々刻々変化していることがわかる.この 周波数変動がゆらぎである. 脳波の周波数ゆらぎを用 いた研究の 1 つとして， $\alpha$ 波の周波数ゆらぎと快適性

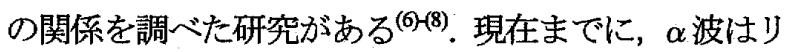
ラックスしているときに， $\theta$ 波はぼんやりしていると きに支配的になることが知られている，本研究で用い る感情モデルは気分と覚醒感という次元を有しており， 気分に関連する $\alpha$ 波と，覚醒に関連する $\theta$ 波の周波数 帯域を解析する価值はあると考える，そこでゆらぎス ペクトルを求める周波数帯域には, $\theta$ 波帯域 $(4 \sim 8 \mathrm{~Hz})$ と $\alpha$ 波帯域 (8〜13Hz)，そして $\theta-\alpha 1$ 波の帯域 (4〜 $10 \mathrm{~Hz}$ ）を利用する．これらの帯域のゆらぎをウォルシ 二変換してパワースペクトルを求める. 横軸に周波数, 縦軸にパワー值をとった両対数グラフ上に求めた值を プロットすると，右下がりのグラフになるが，ある点

（変曲点）を境にその傾きが変化している（図 2）。 そして，この変曲点の左側，つまり低周波数領域の傾 きが-1 に近づくほど快適感を示寸傾向があることがわ かっている.

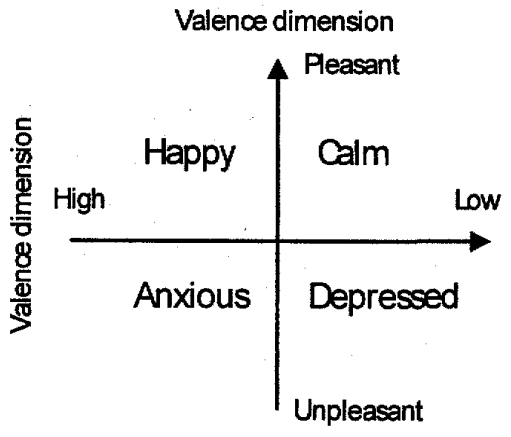

Fig.1 Emotional model

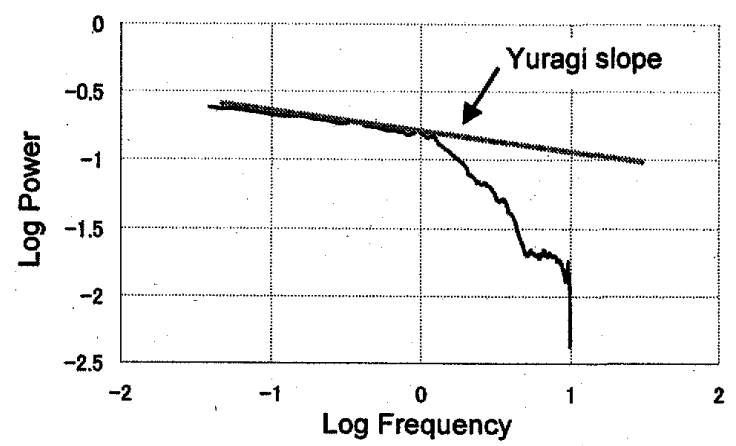

Fig.2 Yuragi power spectrum 


\section{3. 脳 波 測 定}

3・1 譄波測定装置 脳波はマルチテレメータシ ステム (WEB-5000: 日本光電製) で測定し，無線で受 信機へ送る.テレメータの受信機が受け取ったデータ は $\mathrm{AD}$ 変換器 (PCD-320A : 共和電業製) を通して PC で記録される。 また，データの解析は実験後に行う。

$3 \cdot 2$ 䏚波測定位置 脳波測定は一般的には標準 電極配置法である 10/20 法で行われるが, 本研究では， 測定の簡便さを考慮し，感情との関連が深いとされて いる前頭連合野のうち左右前頭部に注目した，電極位 置を固定した電極バンドにより，頭に巻くだけで簡単 に電極を貼り付けられるようにした，電極の位置は眉 間点加ら高さ $35 \mathrm{~mm}$ ，左右 $32 \mathrm{~mm}$ (図 3) . 左右両耳架

（A1，A2）連結を基準として左右前頭部（Fp1，Fp2） にて電位を測定し，Fp1，Fp2 の中点にアース（E）を とった. 本研究での測定は電位活性のない耳架を規準 とし，前頭部との電位差を測る単極誘導法で行う事と するが，これは心理学や人間工学の分野で一般的な導 出方法でもある。

$3 \cdot 3$ 実験条件 実験は図 4のように無響室で行 い，被験者は閉眼で椅子に座った状態とし，ステレオ スピーカーから環境音を呈示した. 30 秒の無音状態と， 環境音を 300 秒流した時の脳波を測定した（図 5）. 実験終了後, 気分と覚醒感を 4 段階で評価してもらっ た（図 6）。また，実験を行う上で，被験者には眠る ことを意識させることで，「眠りを誘発させる音 = 快 適な音」，一方で「眠りを妨害させる音＝不快な音」 といったように，主観的にも客観的にも快・不快に感 じる音を明確に評価できるようにした。

\section{$3 \cdot 4$ 周波数ゆらき解析 実験によって得たデー} 夕の解析方法を示寸. 解析の流れは次のとおりである.

1）実験で得た脳波データから，带域フィルタを通す ことによって任意の帯域を取り出し，ある一定の電 位に達した点のみを検出することで, 周期を求める.

2) 検出した周波数ゆらぎを実際に測定した時間との 対応をとるために $20 \mathrm{~Hz}$ で再サンプリングする.

3) 周波数ゆらぎの時系列波形を 512 点ごとの区間に 分割し，それぞれの区間でウォルシュ変換を用いて ウォルシュパワースペクトルを求め, 10 点での移動 平均を行ったものをその区間のパワー值とする.

4) 区間ごとに求めたパワー值を平均し，実験デー夕 のパワー值とする(ゆらぎスペクトル).

5) 両対数グラフ上に 4)で求めたデ一タを縦軸に，対 応する周波数を縦軸にとる.
6）5)のグラフで変曲点を境に，それより低周波数領 域で直線適合し，その直線の傾きを求める。

以上のような手順で算出したゆらぎの傾きをもとに, 脳波による感情評価を行う。すでに述べたように，左 前頭部脳波(Fp1)より算出したゆらぎの傾きは気分 (Valence), 右前頭部脳波(Fp2)より算出した傾きは覚醒 度(Arousal)に関連するため, 傾きの值から感情モデル に沿った評価が可能である．また，実験終了後のアン ケート調査でも気分と覚醒度について評価しているの でアアンケート結果も同様にして感情モデル上に表す ことができる，したがって，脳波解析結果が示す感情 とアンケート結果が表す感情にどのような関係がある かを容易に見ることができる。

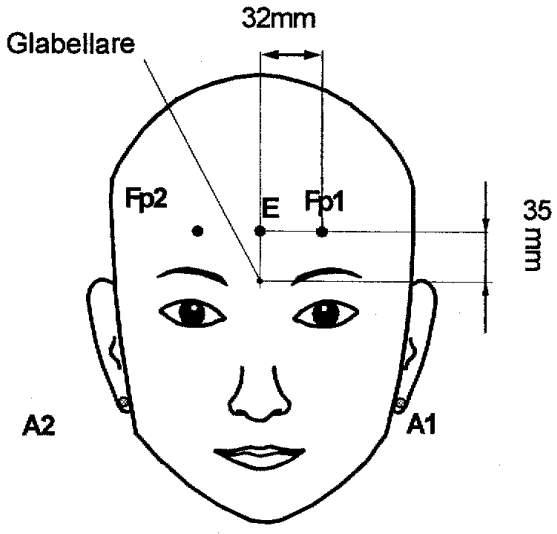

Fig.3 EEG electrode position

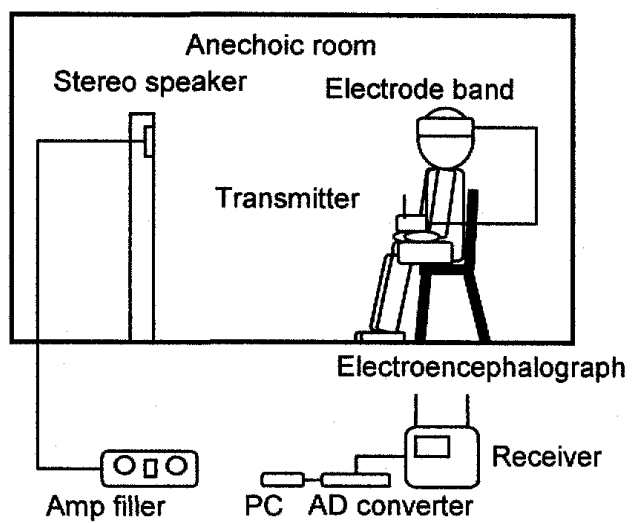

Fig.4 Experimental apparatus

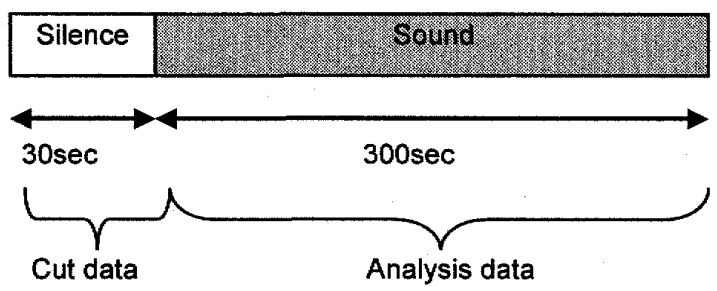

Fig. 5 Measurement process 1 


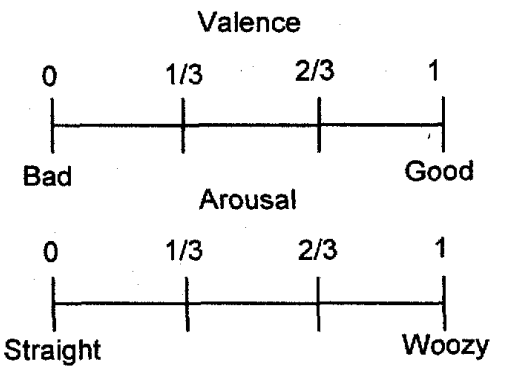

Fig.6 Questionnaire

\section{3-5 $\alpha$ 波の時間変化 人間が一定の感情を} 保つことができる限界は 300 秒であると言われて いる。これを参考に脳波测定時間を設定したが, 実験終了後の感想として，「音に慣れた」，「徐々 に気分が悪くなった」など，音を聴いている間に 感情の変化があったという意見が多かった．そこ で，取得した 300 秒全てのデータを平均すること で得られるデータを見るだけではなく，一定時間 毎にデータを平均し，脳の活動度の時間変化を確 認する.ここでは前半 150 秒と後半 150 秒のデー 夕に分け，データ毎に活動度を調查する（図 7）。 この調查にはストレス変化に対応がある $\alpha$ 波の増 減による評価を行う。 $\alpha$ 波はリラックスした状態 や，落ち着いた状態に増加するとされ，快適感と $\alpha$ 波が関連することが知られている．また， $\alpha$ 波 の中でも周波数帯ごとに $\alpha 1$ 波 $(8 \mathrm{~Hz} \sim 10 \mathrm{~Hz})$ と $\alpha$ 2 波 $(10 \mathrm{~Hz} \sim 13 \mathrm{~Hz})$ に分類して評価を行った研究 (1)があり,ストレス変化には特に $\alpha 1$ が対応してい ることが報告されている，本研究ではこれを踏ま え， $\alpha$ 波の割合の変化だけでなく， $\alpha 1$ 波および $\alpha 2$ 波の割合の変化を調査する.これにより環境 音が人間の精神状態の変化に与える影響を客観的 に見ることができると考える。

\section{4. 瓄境音の快適性評洒結果}

4.1 快適性評価結果図 8～図 10 に冷蔵庫 の音に対する快適性評価結果を示す，グラフは極 座標表示であり，Fp2 のリズム度を $\mathrm{x}$ ； Fp1 のリ

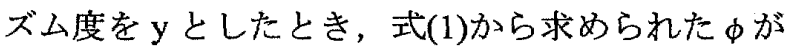
定める領域が感情を表し, 式(2)から求められた $\mathrm{r}$ が快適度（\%）を表す。快適度は各領域に下限と 上限があり，その值により第 1 象限が快適（快適 度: $60 \sim 100 \%$ ), 第 2 第 4 象限がやや快適 (快適度: 40 ～80\%），第 3 象限が不快（快適度:0〜40\%）であ ると位置付ける。

$$
\begin{aligned}
& \phi=\arctan \left(\frac{y-0.5}{x-0.5}\right),(0.5 \leq x \leq 1) \\
& \phi=\arctan \left(\frac{y-0.5}{x-0.5}\right)+\pi,(0 \leq x \leq 0.5) \\
& r=\sqrt{\frac{x^{2}+y^{2}}{2}} \times 100
\end{aligned}
$$

それぞれの図は $\theta$ 波帯域（4～8Hz）を用いた結 果， $\theta$ 波- $\alpha 1$ 波帯域（4〜10Hz）を用いた結果， $\alpha$ 波帯域（8～13）を用いた結果を示している， $\alpha$ 波帯域を用いた場合ではアンケート結果と解析結 果は対応していないが， $\theta$ 波や $\theta-\alpha 1$ 波帯域を用 いた場合ではある程度対応が見られる，次に，他 の環境音（1)実験室の暗騒音，(2)掃除機の音，(3) 冷蔵庫の音, (4)舗装工事現場の音, (5)ビニール袋 の音, (6)電気街の雑踏, (7)国道脇の音, (8)駅前広 場の雑踏, (9)モスキート音, (10川川せせらぎの音) に対しても同様に評価を行い，各環境音に対して 快適性を示した（快適，やや快適であると示した） 人数を図 11 図 13 に示す。これを見てむ， $\theta$ 波 や $\theta-\alpha 1$ 波帯域を用いた場合でのアンケート結果 と脳波解析結果が対応しており，これらの帯域の ゆらぎを使用することで客観的に快適性を評価で きることがわかった。

アンケートによる主観的な結果と脳波解析による客 観的な結果を見ると, (1)実験室の暗騒音, (3)冷蔵庫の 音, (10)川のせせらぎが快適感を誘発させる傾向があり， (4)舗装工事現場の音, (6)電気街の雑踏は不快感を誘発 させる傾向があることがわかった。

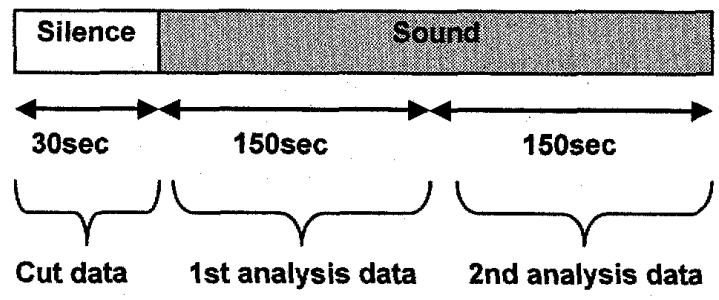

Fig.7 Measurement process 2

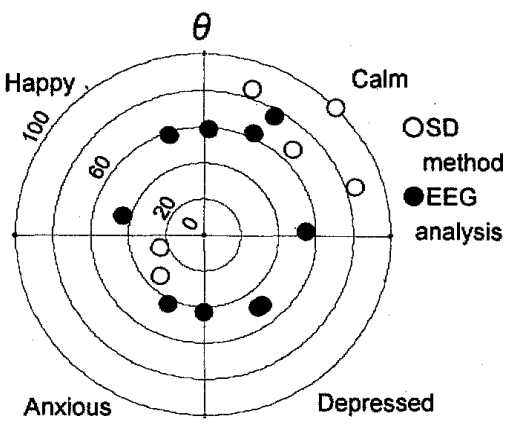

Fig.8 Evaluation result of refrigerator by $\theta$ wave 


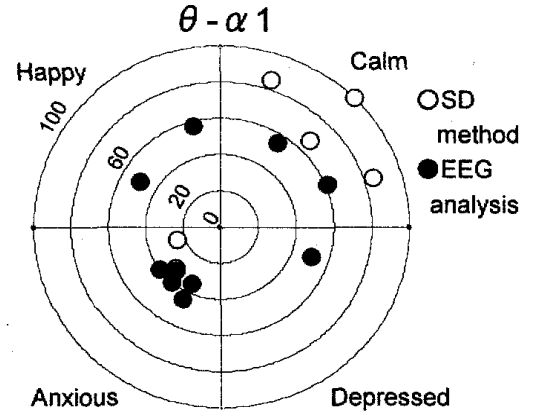

Fig.9 Evaluation result of refrigerator by $\theta-\alpha 1$ wave

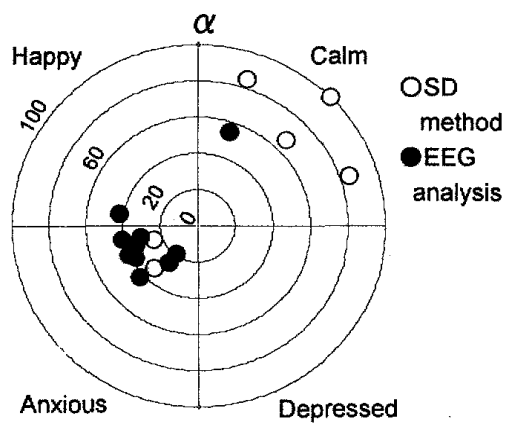

Fig. 10 Evaluation result of refrigerator by $\alpha$ wave

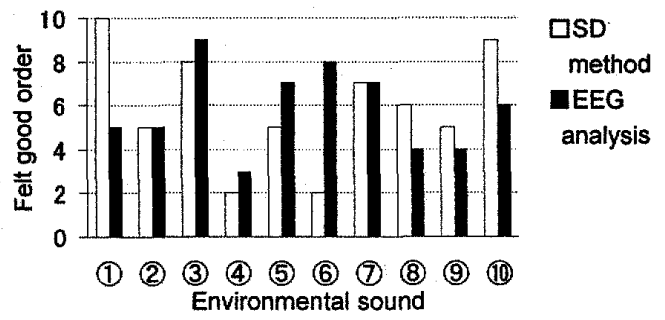

Fig.11 Number of subject felt good by $\theta$ wave

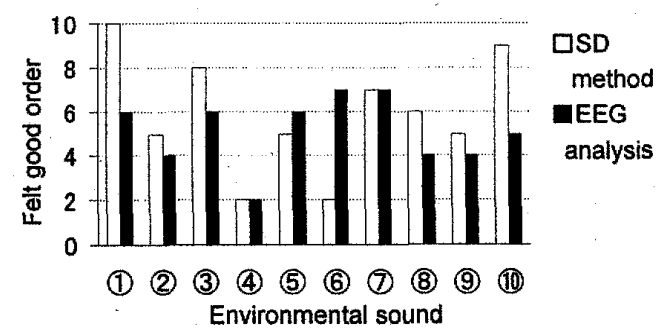

Fig.12 Number of subject felt good by $\theta-\alpha 1$ wave

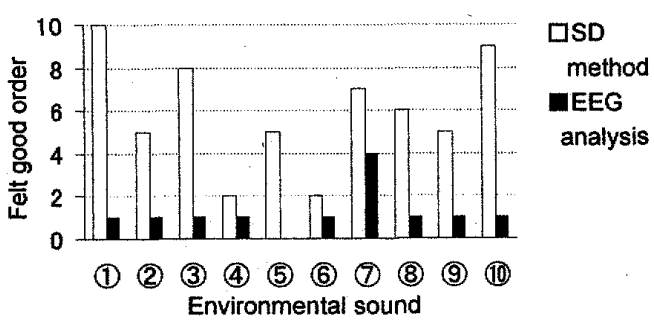

Fig.13 Number of subject felt good by $\alpha$ wave
4.2 $\alpha$ 波の時間変化結果 図 14〜図 23 に各環 境音を聴いた時の $\alpha$ 波の時間変化を示寸，結果は測定 条件ごとの平均で, 横軸の「former half」は前半の脳波 データであり，「latter half」は後半の脳波データを示 す. 絉軸は $\delta$ 波を除く基本律動波における $\alpha 1$ 波と $\alpha 2$ 波の割合，そしてその合計の $\alpha$ 波の割合を示す． $\delta$ 波 を除いた理由はローカットフィルタによる影響を考慮 したためである。

ストレスに関連があるとされている $\alpha 1$ 波について 見ると, 変化が顕著であるのは図 14 の「実験室の暗騒 音」と図 17 の「舗装工事現場の音」である. 前者は減 少する傾向が見られ，後者は増加する傾向が見られる. この 2 つ音は「静かな音」と「うるさい音」であり， 前述のアンケート結果からも相対する環境音であるこ とがわかる.ここで図 17 に注目すると，音呈示前半に おける $\alpha 1$ 波の含有量が $20 \%$ と他の音に比べて低いこ とがわかる.これはこの音が呈示された当初は非常に 不快であることを示していると考えられ，時間がたつ ことで「慣れ」が発生し，30\%付近まで増加したもの であると考える，一方，「実験室の暗騒音」では後半 が前半に比べて小さくなっており， $\alpha$ 波全体を見ても 減少傾向にあることがわかる.これは実験中には被験 者に対して眠ることを意識させているので，低覚醒時 に優位になる $\theta$ 波の影響であると推測できる.このこ とは，図23の「川のせせらぎ」においても，同じよう な傾向があることからむ説明がつく，「実験室の暗騷 音」の他では $\alpha$ 波全体が減少するというはっきりとし た傾向が見られない，他の環境音に関しては，「舗装 工事現場」に比べると顕著な $\alpha 1$ 波の増加は見られな いものの，ある程度の増加は確認できる. よって他の 環境音でも音呈示前半と音呈示後半で「慣れ」が発生 していることが確認できたといえる. 例外として図 19 の「電気街の雑踏」について確認する.「電気街の雑 踏」は通行人の話し声の割合が多く，周波数や音の変 化が大きい，そのため，音に慣れることができず，ス トレスが大きくなり，結果として $\alpha 1$ 波の減少につな がったと考えられる．このことから，音の変化が大き く断続的な環境音は「慣れ」が発生しにくく，逆に音 の変化が少ない環境音，また，その変化が規則的な環 境音ものは「慣れ」が発生しやすいと考えられる。 


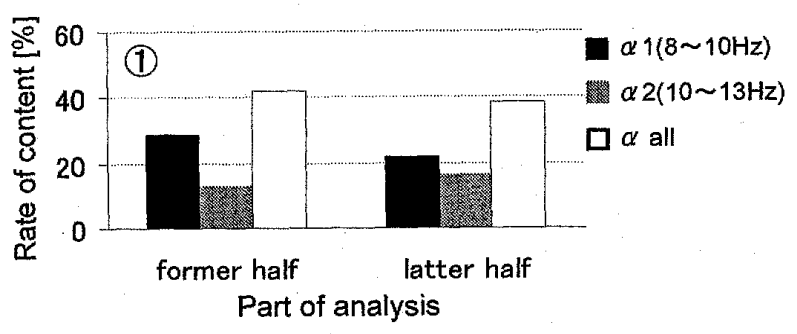

Fig. 14 Shift of $\alpha$ wave ratio for background noise

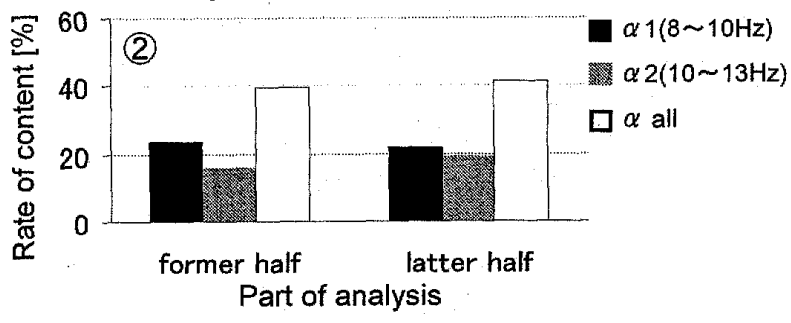

Fig.15 Shift of $\alpha$ wave ratio for cleaner

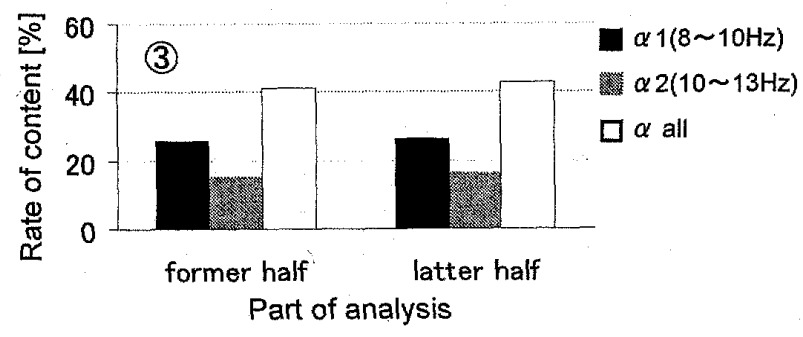

Fig.16 Shift of $\alpha$ wave ratio for refrigerator

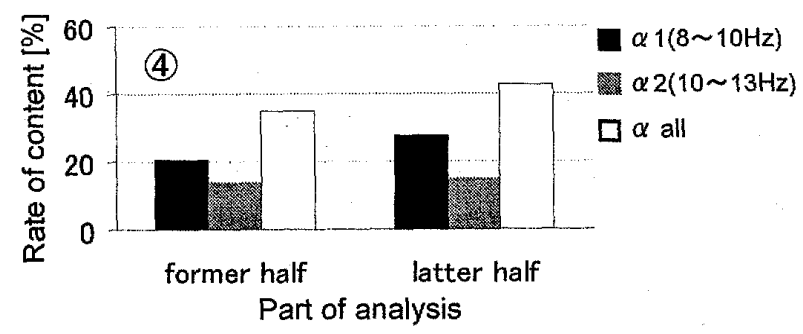

Fig.17 Shift of $\alpha$ wave ratio for pavement construction

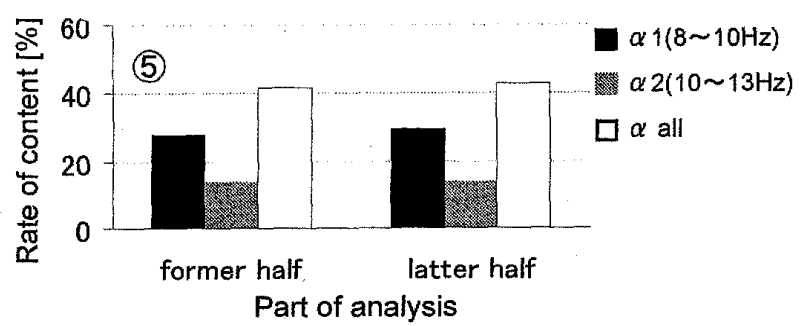

Fig.18 Shift of $\alpha$ wave ratio for plastic bag

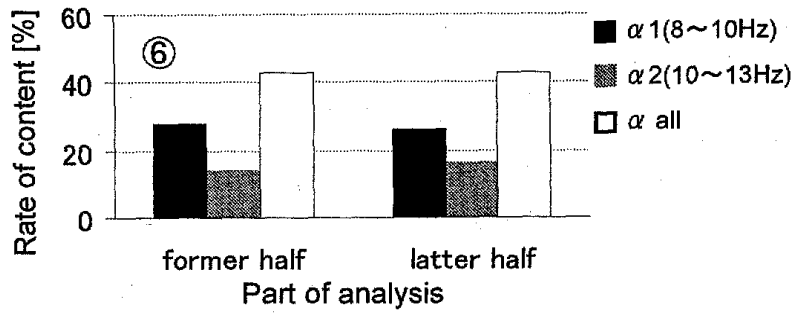

Fig.19 Shift of $\alpha$ wave ratio for electronics quarter

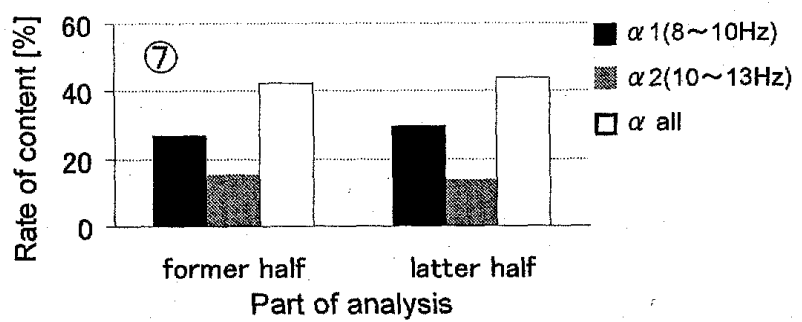

Fig.20 Shift of $\alpha$ wave ratio for side of road

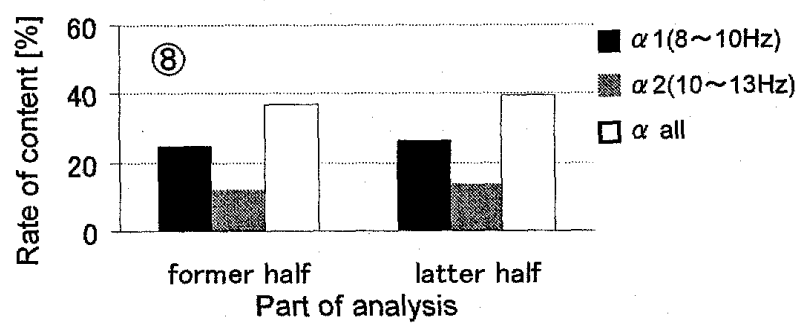

Fig.21 Shift of $\alpha$ wave ratio for station square

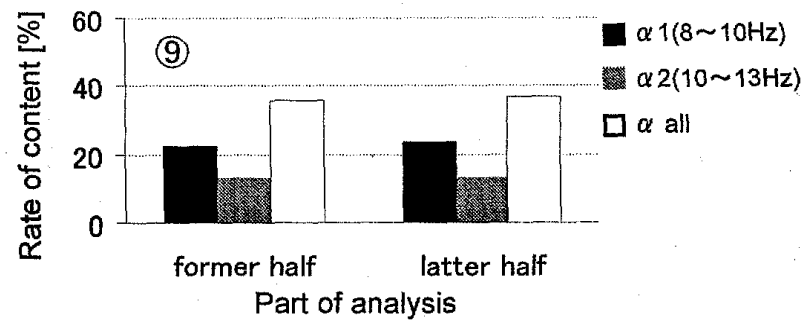

Fig.22 Shift of $\alpha$ wave ratio for mosquito noise

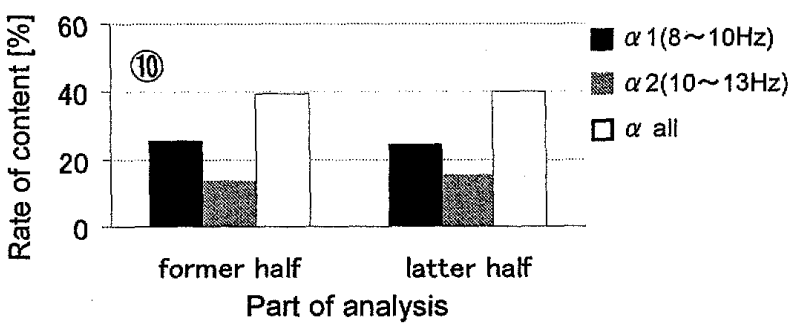

Fig.23 Shift of $\alpha$ wave ratio for chatter 


\section{5. 結}

本研究から以下のことがわかった。

(1) $\theta$ 波帯域または $\theta-\alpha 1$ 波の带域を使用してゆらぎ 解析を行った結果はアンケート結果と近くなり，あ る程度快適性の評価ができる。

（2）環境音に対する主観的及び客観的な快適性評価を 行った。

（3） $\alpha$ 波の増减加ら，音に対する「慣れ」を確認する ことができる.

（4）音の変化が大きい環境音は「慣れ」が発生しにくく， 逆に音の変化が少ない環境音, また，その変化が規 則的なものは「慣れ」が発生しやすい.

本研究では，主観的評価方法である SD 法を用いず に客観的に快適性を評価することを目標とし，その力 法として脳波の周波数ゆらぎに注目した．第一段階と して環境音を取り上げ，その快適性について検討した 結果，脳波を用いてある程度環境音の快適性を評価で きることがわからた．また，音に対する「慣れ」を判 断できそうであることもわかった。

脳波を用いた快適性評価方法の妥当性を検証するに は，より多くの被験者や情報を用いて統計的処理が必 要であり，今後検討していきたいと考えている.
(1) Kawai, K., Kojima, T., Hirate K., Yasuoka M., , Personal psychological evaluation structure of environmental sounds: Experiments of subjective evaluation using subjects' own terms, The Journal of the Acoustical Society of Japan, Vol.60, No.5(2004), pp.249-257.

(2) Okamoto, Y., Fukushima, Y., Sakaguchi, T., Arai, J., Choi, J., Hotta, K., Yoshida, T., The effect of Sound field containing the Supersonic wave on the Psycho physiological condition, Technical report of IEICE. EA, EA2003-65(2003), pp.51-58.

(3) Yamazaki, K.., Hotta, K., Saitou, M., Ogawa, M., On the physiological effect of ultrasound included in the mountain stream sound, The Journal of the Acoustical Society of Japan,Vol.64, No.2 (2008), pp.545-550.

(4) Randolph R Comelius, THE SCIENCE OF EMOTION: Research and tradition in the psychology of emotions, Seishin Shobo (1999).

(5) Wendy Heller, Neuropsychological Mechanisms of Individual Differences in Emotion, Personality, and Arousal, Neuropsychology, Vol.7, No.4 (1993), pp.476-489.

(6) Yoshida, T., The measurement of EEG frequency-fluctuation and evaluation of comfortableness, The Joumal of the Acoustical Society of Japan, Vol.46, No.11 (1990), pp.914-919.

(7) Yoshida, T., The Evaluation of Emotion Using the Measurement of Frequency-Fluctuation of Brain Wave, Journal of the Japan Society of Mechanical Engineers, Vol.98, No.918 (1995) , pp.403-406.

(8) Yoshida, T., Objective Measurement and Evaluation for Comfortableness, Journal of the Society of Instrument and Control Engineers, Vol.41, No.10 (2002), pp.696-701. 